\title{
A módosított messenger RNS-terápia lehetőségei a kardiális regenerációban
}

\author{
Szabó Gábor Tamás \\ Debreceni Egyetem, Kardiológiai és Szívsebészeti Klinika, Debrecen \\ Levelezési cím: nszgt@med.unideb.hu
}

A világ fejlett országaiban amellett, hogy vezetik a halálozási statisztikákat, nagy kihívást jelent a kardiovaszkuláris megbetegedések és köztük a szívizom-károsodás következtében kialakuló szívelégtelenség (SZE) kezelése. Ugyan az elmúlt években jelentős elörelépések történtek, amelyek segítségével mind a várható élettartam, mind az életminőség javitható ezen kórképekben, az SZE hátterében álló ok megszüntetésére és a betegség során elvesztett cardiomyocyták pótlására széles körben elérhető megoldás egyelöre nem áll rendelkezésre. A felnőtt emberi szív saját regeneratív képessége igen alacsony, azonban az elmúlt években szerzett molekuláris biológiai ismeretek több esetben igazolták, hogy a különböző szabályozási mechanizmusok módosításával lehetséges a cardiomyocyta-protekció, az érújdonképződés, sőt a cardiomyocyta-proliferáció elérése is. Az őssejtterápiákkal végzett kísérletekből származó tapasztalatok rávilágítottak a nem sejtalapú megoldások előnyeire. Ezek között a genetikai terápia alkalmasnak bizonyul a kardiális regenerációban szerepet játszó, fehérjetermészetű szabályozó elemek celluláris, vagy extracelluláris jelenlétének biztosítására. Ígéretes a módosított messenger RNS alkalmazása, amely segítségével a genetikai információ a megfelelő sejtekhez juttatható el biztonságos módon. Az így termelődő proteinek jól kiszámítható időbeni és mennyiségi dinamika mellett jelennek meg.

Kulcsszavak: kardiális regeneráció, non-celluláris regenerációs terápia, genetikai alapú terápia, módosított mRNS-terápia

\section{Modified mRNA as a therapeutic option in cardiac regeneration}

Cardiovascular diseases including heart failure are the leading causes of death in the industrialized countries and their prevention and treatment are one of the challenging tasks for cardiologists. In spite of the significant effort to improve both life expectancy and quality of life of patients suffering from these diseases, no widely available and effective treatment exists for the replacement of lost cardiomyocytes. The adult human heart has a very low regenerative capacity. In the past years, data had surfaced from various experimental and clinical research indicating that cardiomyocyte protection, angioneogenesis, as well as cardiomyocyte proliferation are all feasible via the modification of different signaling mechanisms. Observations deriving from stem cell experiments highlighted the advantages of cell-free therapies. For instance, gene therapy is a great avenue to replace proteins necessary for cardiac regeneration at a desired concentration. Delivery of genetic information to the appropriate cells with modified mRNA is a promising and safe way to ensure transient and well-controlled protein secretion and immunogenicity.

Keywords: cardiac regeneration, non-cellular regenerativ therapy, gene therapy, modified messenger RNA

A kézirat 2020. 02. 13-án érkezett a szerkesztőségbe, 2020. 03. 19-án került elfogadásra. 


\section{Bevezetés}

A szív igen komplex, diverz sejtekből felépülő szerv, amely már az intrauterin 3-4. héten müködni kezd, és folyamatos mủködése elengedhetetlen mind a fötális fejlődéshez, mind a teljes posztnatális élethez. Elfogadott az a tény, hogy a felnőtt emberi szervezet szívizomsejtjei csak minimális mértékben képesek megújulni. A születés után bármely okból történő jelentősebb szívizomterület-elhalás teljes spontán pótlódása funkcionáló szívizomszövettel nem várható $(5,6)$.

Emiatt is kiemelten fontosak a rendkívüli előrelépések a kardiológiában, amelyek az iszkémiás szívbetegség, az akut szívizominfarktus és a következményes szívelégtelenség (SZE) kórformák megelőzésére és kezelésére irányulnak. Az elmúlt évek jelentős eredményei dacára a fejlett országokban továbbra is az említett kórképek vezetik a haláloki statisztikákat. Sőt az aktuális adatok alapján az SZE kialakulása és halálozása az elmúlt években az intervenciós és gyógyszeres stratégiák optimalizálása és szélesebb körü alkalmazása ellenére is növekedést mutat $(1,2,3,30)$.

Az SZE kezelése nagy kihívást jelent, főként progreszszív lefolyás, valamint az előrehaladott, illetve végstádiumú állapotok esetén (4). A szervpótlást biztosító, Magyarországon kimondottan jól szervezett és világviszonylatban is kiemelkedő eredményeket felmutató szívtranszplantációs program sem tud minden betegnek megfelelő megoldást nyújtani. Egyéb terápia, amely a betegség hátterében álló, az elvesztett funkcionáló szívizomsejttömegek pótlását célozná, nem elérhetö.

Az elmúlt évtizedekben a molekuláris biológiai technikák robbanásszerű fejlődése vezetett oda, hogy számos, a szív kialakulásában és az életkorhoz, vagy a különböző betegségekhez kapcsolódó változásokban szerepet játszó, többszörös szabályozó útvonalak, az ezekben részt vevő különböző sejttípusok, valamint a szabályozást irányító transzkripciós faktorok és mediátorok felismerésre és leírásra kerültek.

Nem vitatható a jelentősége azoknak a vizsgálatoknak, amelyek a komplett kardiális regenerációra képes halak és kétéltǔek szabályozási folyamatainak megértésére irányultak. A föként zebrahallal, szalamandrával és tarajos gőtével történt kísérletek eredményei nagyban segítették a magasabb osztályba sorolt gerincesek kardiális regenerációjának, illetve ezen képesség elvesztésének megértését is $(57,34)$.

Emlősökön végzett kutatások között mérföldkőnek számított az a közlemény, amely egerekben vizsgálta a születés utáni szívizomsejt-proliferációt. Ebből a tanulmányból vált egyértelmúvé, hogy a cardiomyocyták regenerációs potenciálja a születés utáni 7. napon szűnik meg (7). A további emlősfajokban, az infarktus esetén létrejövő génexpressziós válasz pontosabb leírása mutatott rá a szabályozó folyamatok hasonlóságára (63, 64).
A kutatásokból származó ismeretek szintézise nyitotta meg az utat a kardiális regeneráció lehetősége előtt is, rámutatva, hogy a különböző sejtek és azok változásai, valamint a háttérben álló szabályozó útvonalak elemei mind potenciális targetként szerepelhetnek a sejt- és szövetpótló terápiák számára.

\section{A regeneráció megoldási alternatívái}

Mivel SZE során meghatározó és kedvezőtlen folyamat a nagy mennyiségü, funkcionáló cardiomyocyta elvesztése, reális alternatíva lehet ezen sejtek pótlása sejtterápiás eljárással. A transzplantált sejt forrása, differenciálásának technikája, a bejuttatás helye és módja számos megoldandó problémát vetett fel. Köztük első számú annak megítélése és vizsgálata volt, hogy önmagában a sejtek vagy egy sejttípus bejuttatása elegendő-e. Egyik legfontosabb szempont, hogy a kialakuló új szövetnek mind anatómiai értelemben, mind pedig a nehezebben modellezhető elektromechanikai asszociáció mentén is tökéletesen illeszkednie kell a szív teljes szövetéhez.

Számos próbálkozás és vizsgálat történt az optimális cardiomyocyta-forrás megtalálása érdekében (8). Ezek között szomatikus ős- és progenitor sejtekkel, de kardiális rezidens C-kit (+) őssejtekkel történt számos preklinikai és később humán vizsgálat is. A nagy várakozás ellenére egyértelmű, konzekvensen pozitív, meggyőző eredmények nem születtek (65). Ugyan a vizsgálatokban kimutatható volt a balkamra-funkció javulása, ennek hátterében a bejuttatott őssejtek traszdifferenciációja nem volt egyértelmüen igazolható. Bár a korábban alkalmazott sejttípusok kiválasztásánál számos érv felsorakoztatható volt, a jelenlegi eredmények birtokában az indukált pluripotens őssejtek alkalmazása tűnik optimálisnak. A sejtterápiás eljárások eredményeit és következményeit elemezve került mindinkább egy másik fontos ismeret a vizsgálatok középpontjába, miszerint a bejuttatott őssejtek különböző parakrint szabályozó faktorok kibocsátásával alakítják a mikrokörnyezetet (42). Emellett az immunválasz centrális szerepére mutat rá egy tanulmány, amely az őssejtek intramiokardiális bejuttatása során a kialakuló kedvező klinikai paraméterváltozásokat az akut immunválasz során az aktivált makrofágok által az infarktus széli zónában indukált hatásaival magyarázza (43).

A parakrinfaktorok identifikálása, szerepüknek pontosabb megértése összekapcsolódott a szív szöveti fejlődésének, valamint a különböző kórképekben jelentkező eltérések molekuláris alapjainak részletes feltérképezésével. Az ismeretek felhasználásával az ún. nem celluláris alapú kardiális regenerációs technikák előtt nyílt meg az út.

A sejtterápiás módszerekkel végzett kutatások és ezen eljárásokból szerzett tapasztalatok igazolták különböző SZE-modellekben, hogy több növekedési faktor, illetve 
peptid bejuttatásával a felnőtt szívben jelenlévő, érett cardiomyocyta-proliferáció és endothelregeneráció, valamint angioneogenezis és vaszkulogenezis érhető el. $A$ nem celluláris alapú megoldások tehát a szívben lejátszódó folyamatok szabályozásában részt vevő faktorok bejuttatása lett, amelyekkel a fö cél a cardiomyocyták proliferációjának, az angioneogenezisnek és a vaszkuloneogenezisnek, a cardiomyocyta-apoptózis gátlásnak, valamint a cardiomyocyta-elhalás következtében kialakuló immunválasz modulálásának elérése.

Lehetetlen volna az eddig leírt összes szabályozó út és target részletes ismertetése az összefoglaló közlemény keretei között, így az alábbiakban a legrészletesebben vizsgált, több esetben humán tanulmányban is szereplő faktorok kerülnek említésre.

A legelső sikeres próbálkozások a sejtciklus szabályozásában részt vevő ciklinekkel és ciklindependens kinázokkal (CDK) történtek. Több faktor (ciklin-B1, ciklin-D1, CDK1, CDK4) overexpresszálásával cardiomyocyta-proliferáció volt elérhető (56).

Biztató eredmények születtek többek között IGF-1 (insuline-like growth factor1) alkalmazásával, amely növekedési faktor a szívizomsejtekben részt vesz a növekedés és metabolizmus irányításában. Felismerték, hogy myocytaproliferációt biztosító hatása a MAPK(mitogen-activated protein kinase) és a PI3K- (phosphatidyl-inositol 3-kinase) útvonalak és az ERK- (extracellular signal-regulated kinase) tengely aktiválásához kötődik. Remodellinggátló hatását, valamint progenitorsejt-aktivációs képességét nagy, szívizom-iszkémiás állatmodellben sikerült igazolni (59).

Több tanulmány irányult az NRG1 (neuregulin-1) hatásának megértésére. Ezek között rekombináns fehérjeként alkalmazva több humánvizsgálat is történt, amelyek eredményei megfelelő tolerálhatóságról számoltak be krónikus szívelégtelen betegpopulációban remodellinggátlással és következményes javuló kardiális funkcióval $(44,60)$.

Az FGF-1 (acidic fibroblast growth factor-1) egy, a szívizom, endothelsejtek, makrofágok és fibroblastok által is szekretált peptid. Szívizom-iszkémia esetén a szekréció mértéke emelkedik. Vizsgálatok a kardiális regeneráció vonatkozásában pozitív hatását igazolták, amelyet az apoptózis gátlása révén ér el.

Az extracelluláris mátrix fehérjék között a periostin, az agrin és az epikardiális eredetű FSTL-1 (follistatin-related protein 1) alkalmazása mellett myocytaproliferációt sikerült kimutatni. A vizsgálatokban elért különböző hatások a fenti proteinek funkciójának különbözőségére utal az újszülött, illetve felnőtt szívizom-károsodás esetén $(45,46,47,52)$.

A cardiomyocyta-sejtosztódás elérése mellett a kardiális regeneráció szempontjából a vaszkulogenezisnek és angiogenezisnek is kitüntetett szerepe van. Ezen a területen a VEGF (vascular endothelial growth factor) szignalizációs fehérjék hatásainak feltérképezése történt meg legrészletesebben. Az angioneogenezis irá- nyításában emellett a korábban már a myocytaproliferáció során is említett IGF-1 és FGF, továbbá SDF-1a (stromal cell-derived factor $1 \alpha$ ) és TGF- $\beta$ (transforming growth factor $\beta$ ) szerepét is igazolták iszkémiás modellekben (58).

Az endotheliális növekedési faktorok között a VEGF-Aröl rendelkezünk a legtöbb ismerettel. A pontos kardiális hatás igazolására számos iszkémiás állatmodellben, később humán fázisvizsgálatban is vizsgálták az angiogén faktor szerepét. A VEGF-A rekombináns protein formájában és génterápiás eljárások segítségével is alkalmazásra került, a bejuttatást pedig intravénás, intramiokardiális, peritoneális és intrakoronáriás út mellett biodegradábilis scaffold segítségével is megpróbálták optimalizálni. A vizsgálatok jelentős különbségeket mutattak az érújdonképződés és következményes kardiálisfunkció-javulás vonatkozásában $(49,50)$.

Természetesen adódik a lehetőség, amelyek több kísérletben alkalmaztak is, hogy a celluláris, azaz sejttranszplantáció kombinálható a nem celluláris faktorok adásával.

Sőt elegáns megoldásként merült fel a szívben jelenlévő, nem cardiomyocyták és nem endothelsejtek különböző transzkripciós faktorokkal történő újraprogramozása. Egyik legalkalmasabb jelöltnek a nagy arányban jelenlévő fibroblastok bizonyultak. Jelentőségüket tovább fokozza, hogy szívinfarktust követően ez a sejttípus játszik elsődleges szerepet a hegszövet kialakításában is $(9,10)$. Az elmélet első sikeres gyakorlati megvalósítása cardiomyocyta-traszkripciós faktorok (Gata4, Mef2c, Tbx5) génterápiás adásával sikeres volt, funkcionáló szívizomsejteket sikerült létrehozni fibroblastok átprogramozásával (48).

Mivel ezek a faktorok döntően fehérjetermészetű anyagok, a megfelelő sejt eléréséhez, a szükséges koncentráció biztosításához, az immunogenitás kérdéseinek megválaszolásához sok új megoldást kellett kidolgozni. A bejuttatott protein féléletideje, instabilitása és az általa kiváltott immunválasz kritikus a vizsgálatokban. További nehézségként jelentkezik az exogén forrásból származó protein intracelluláris bejuttatása.

A fent felsorolt akadályok leküzdésére reális lehetőségként adódott a genetikai terápia. Nukleinsavak bejuttatásával biztosítható a szükséges aminosavsorrend-információ, amely a megfelelő fehérje megfelelő helyen történő szintéziséhez szükséges. A génterápia izgalmas megoldás a kardiális regenerációban is. Segítségével precízebben érhetjük el a módosítani kívánt szabályozó útvonalat.

\section{Génterápiás lehetőségek}

A génterápia lehetőséget nyújt a szervezetben lejátszódó folyamatok módosítására a DNS-ben meghatározott gén információja és expressziója révén termelődő fehérje közötti tengelyen több ponton és több módon. $A$ 
bejuttatni kívánt genetikai információt szállító molekulát felépítő nukleozidok alapján DNS- (dezoxiribonukleinsav-) és RNS- (ribonukleinsav-) terápiákat különíthetünk el. A génterápia nyilvánvaló lehetőségeivel együtt újabb nehézségekre is választ kell adnia a tudománynak, amelyek között kulcskérdés lett a bejuttatni tervezett nukleinsav celluláris transzportjának megoldása.

A nukleinsavak sejtbe és sejtmagba történő bejuttatására virális és plazmid vektorokkal történt kísérlet. Ezen opciók közül az asszociált adenovírus (AAV) bizonyult a legjobbnak, mivel mind immunogenitási profilja, mind a genomba történő integrációja és ezzel onkogén hatása alacsony, mindezek mellett viszont transzdukciós kapacitása megfelelő $(11,12,27)$.

A DNS stabilitása széles felhasználási lehetőséget nyitott annak alkalmazása előtt, viszont a nehezen kiszámítható, a genomba történő integrációja során kialakuló változások, esetleg nem várt késői génexpressziók megváltozása és azok monitorozásának és kontrolljának szükös lehetőségei fókuszba helyezték egyéb alternatív megoldások fejlesztését.

A génterápia másik iránya az RNS bejuttatása vagy módosítása. Az RNS viszonylagos instabilitása sok nehézséget jelentett kezdetben. Először 1990-ben került közlésre tanulmány, ahol hírvivő (messenger - m) RNS-t használtak vektornak in vivo, amit követően funkcionális fehérjét detektáltak (13). Az első sikerek rendkívüli teret nyitottak az RNS alkalmazása előtt, számos úttörő közlemény jelent meg a legszélesebb alkalmazási körben a preventív vakcinálási kísérletektől kiindulva a malignus betegségek genetikai terápiájáig.

Az mRNS-terápia alkalmazásának nagy előnye a DNS-alapú terápiákkal szemben, hogy elegendő a citoplazmába juttatni, nem szükséges elérni a sejtmagot. Szemben a DNS korábban említett legnagyobb veszélyével, miszerint integrálódhat a genomba, mutációkat létrehozhatva ezzel, az mRNS esetén ez a veszély nem áll fent. Az előnyök között kiemelendő továbbá, hogy a genetikai információ alapján termelődő fehérje mennyisége, valamint a termelődés ideje könnyebben tervezhető és modellezhető, szemben a DNS-alapú génterápiás megoldással.

Az mRNS-sel végzett vizsgálatok újabb nehézségekre is rávilágítottak. Az exogén forrásból a szervezetbe bejuttatott mRNS-t a ribonukleáz enzimek gyorsan degradáljak, amely mechanizmus a patogének elleni védekezés egyik fontos eszköze (14). A sejtmembránon átjutó mRNS sincs biztonságban, azt az intracelluláris ribonukleázok darabolják és teszik ezzel hatástalanná $(15,18,19)$. Emellett az exogén mRNS nemcsak könynyen degradálódik, hanem az általa kiváltott immunválasz is extrém mértékü, amely nagyban befolyásolja a tervezett terápia hatásosságát. Az exogén mRNS bejutása után kialakuló immunológiai folyamatoknak, az aktiválódó receptorok és útvonalak összefüggésének megértése fontos állomás volt a terápia alkalmazása szempontjából $(16,17)$.

\section{A módosított mRNS}

Mérföldkő volt az a kutatómunka, amely eredményei alapján született közleményekben Karikó és munkatársai először számoltak be a természetben is előforduló, módosított nukleozidok felhasználásával, in vitro szintézissel készült mRNS alkalmazásáról. Olyan konstrukciót sikerült előállítaniuk, amely módosított mRNS (mod-mRNS) minimálisan volt immunogén, és több fehérje képződését indukálta, mint a módosítás nélküli mRNS $(20,21)$. További vizsgálatok is igazolták a mod-mRNS stabilitásának és a transzláció mértékének fokozódását (55). Az mRNS stabilitását, in vivo biológiai hatását a transzláció effektivitásán alapulva tovább növelte számos újabb, az mRNS teljes szerkezetét érintő poszttranszkripciós módosítás is. Reális lehetőség lett mind a nagyobb szöveti méretek (pl. emberi szív) esetén is megfelelő koncentráció elérése és az immunválasz módosulásából fakadóan többszöri, vagy akár folyamatos alkalmazás. Ezen optimalizálások kiszélesítették az mRNS alkalmazási területét, így a vakcinálás és tumorterápia mellett a ritka genetikai hiánybetegségekben és a regenerációs medicinában is szerephez juthatott.

\section{mod-mRNS allkalmazása a kardiológiában}

A genetikai alapú terápiák közül a kardiológiai alkalmazást nagyban támogatta, hogy a mod-mRNS a kívánt genetikai információ bejuttatásához olyan vektort biztosíthat, amely segítségével a nem osztódó sejtekben is gyors, intenzív fehérjetermelést kiváltó, átmeneti hatást érhetünk el (28).

Kardiális regeneráció céljából adott mod-mRNS in vivo alkalmazásáról 2013-ban számoltak be először. Infarktusos egérmodellben VEGF-A mod-mRNS közvetlen intramiokardiális adásának hatására kifejezettebb VEGF-A-protein-szekréciót detektáltak nem módosított mRNS-terápiához hasonlítva. A terápia csökkentette az infarktus kiterjedését, javította a kamrafunkciót és a túlélést. Az immunválasz vizsgálata igen kedvező eredményt mutatott. A modellben megfigyelhető volt az epikardiális progenitor sejtek (WT1 progenitor cell) aktiválódása, illetve apoptózisgátlás is igazolódott. Külön kiemelendő, hogy a VEGF-A szekréciójának dinamizmusa a mod-mRNS adását követően kedvezőbb, ennek köszönhetően nem alakult ki az egyéb módon (pl. DNS, illetve rekombináns protein alkalmazásával) biztosított VEGF-A-hez képest nemkívánatos vaszkuláris permeabilitásváltozás és következményes myocardiumödéma, illetve abnormális ér újdonképződés sem (22).

A VEGF-A-t kódoló mod-mRNS alkalmazásával elérhető ún. pulzatilis fehérjeszekréció támogatja a humán multipotens Isl1-pozitív (insulin gene enhancer protein ISL-1) sejtek, a kardiális progenitor sejtek egy típusának integrálódását, proliferációját és túlélését (54). 
A fenti sikerek alapozták meg a terápia alkalmazását humán vizsgálatokban is. Ezek között az első tanulmány kiváló biztonságossági és hatékonysági paramétereket igazolt diabéteszes betegeknél intradermális adás esetén (62). A kialakított konstruktummal jelenleg is végeznek humán randomizált klinikai vizsgálatot. Infarktusos egér modellben, intramiokardiálisan injektált IGF-1 mod-mRNS transzlációjának mértéke elegendő volt a cardiomyocyták citoprotekciójára, az Akt(protein kinase $B=P K B=A k t)$ és Erk- (extracellular signal-regulated kinase) foszforiláció módosításával, apoptózis gátlása révén. A modellben a nanopartikulummal történő bejuttatást követően 24 órával kimutathatóak voltak a vizsgált pozitív hatások az infarktusos határterületekben (26).

A FSTL-1 fehérje kardioprotekcióban játszott szerepe myocardium iszkémiás károsodás esetén ismert volt (52). A szabályozó protein-glikoziláció jelentőségének tisztázását követően mutált hFSTL-1-t kódoló mod-mRNS bejuttatásával sikerült rágcsáló, infarktusos modellekben cardiomyocyta-proliferációt is elérni, valamint kimutatni a hegszövet méretének csökkenését és a balkamra-funkció javulását. A vizsgált modellben egyetlen dózis elegendő volt a kívánt hatások eléréséhez (29).

Egy másik állatkísérletben az infarktus során magasabb ceramidszintek esetén provokált apoptózis gátlására mod-mRNS-terápiával bejutatott ceramidáz posztinfarktusos egér modellben csökkentette az infarktusos terület nagyságát, javította a balkamra-funkciót, valamint növelte a túlélést (66).

A mod-mRNS-terápia hatékonysága a megfelelő szabályozó útvonal és annak elemének kiválasztása és az optimális konstruktum megalkotása mellett nagyban függ attól is, sikerül-e elérni a célzott sejtet.

A szívregeneráció in vivo kísérletek esetén a kiterjedten alkalmazott intramiokardiális beviteli mód mellett a különféle vaszkuláris bejuttatási formák is elérhetőek (23). Bár mindegyik alkalmazási módnak megvannak a saját előnyei, klinikai megközelítésben, a jövőbeni felhasználás érdekében a transzkatéteres, perkután megoldások tűnnek reálisnak a mindennapi gyakorlatban, természetesen az intravénás lehetőséget követve.

A szervezetbe történő bejuttatás mellett a mod-mRNS formulációja lesz meghatározó a targetsejt elérésében. A mod-mRNS-terápiák esetén nincs szükség vírusvektorra, a kódolt genetikai információ különböző pufferek és transzfekciós reagensek segítségével, vagy pozitív töltésű polimerekből és lipidekből álló nanopartikulumokba zárva érheti el a célzott sejtet. A különböző formulációs lehetőségekkel történt disztribúciós vizsgálatok alapján a nanopartikulumok alkalmazása tűnik egyelőre a leghatékonyabb megoldásnak a kardiális regeneráció esetén $(24,25)$.

A genetikai információ szállításának optimalizálásához szorosan kötődik az exoszómákkal folytatott megfigyelésekből és vizsgálatokból származó adatok rendszerezése. Az exoszómák, mint kisméretű extracelluláris vezikulumok fontos közvetítői a sejtek közötti kommunikációnak. Számos sejt jelentős számú exoszómát szekretál, amelyeket megfelelő jelölés esetén más sejtek könnyen és gyorsan felvesznek $(40,41)$.

A sejtek endocitózis útján veszik fel a mod-mRNS-t, illetve az ezt szállító partikulumokat. A sejtmembránon átlépve intracelluláris endoszóma alakul ki. Az endoszóma felnyílását követően lesz hozzáférhető a mod-mRNS a citoplazmában.

A mod-mRNS segítségével történő fehérjeképződés dinamizmusát több vizsgálat részletesen elemezte. Az intrakardiális alkalmazásban az uridin módosítása esetén megfigyelhető volt egy magasabb transzlációs érték. A termelődő protein percek múlva kimutatható mind in vitro, mind pedig in vivo vizsgálatokban, a transzláció csúcsa 24 óránál figyelhető meg. Ezután a fehérje jelenléte további kb. 10 napig is észlelhető $(28$, 53).

Annak fényében, hogy mod-mRNS-terápia segítségével cardiomyocyta-proliferáció (29), apoptózisgátlás $(26,66)$, valamint angiogenezis (22) is elérhető iszkémiás emlős állatmodellekben, sőt bizonyos területen már humánadatokkal is rendelkezünk, a kardiális regeneráció ezzel a technikával nem is tűnik igazán futurisztikusnak.

\section{Egyéb RNS-terápiák}

Külön összefoglalóra lenne szükség a mod-mRNS mellett elérhető egyéb, RNS-t célzó terápiák részletezésére, itt csak rövid, említésszintű áttekintésre nyílik lehetőség. Ismert, hogy a génkifejeződés finomhangolásában több rövid RNS-szakasz is részt vesz. Az ún. nem kódoló RNS-ek, mint a mikro RNS-ek (miRNS, miR), hosszú nem kódoló RNS-ek (IncRNS), a cirkuláris RNS-ek (circRNS) és a kis interferáló RNS-ek (siRNS), valamint egyéb oligonukleotid alapú molekuláris terápiák (agomiR, ASO - antiszensz oligonukleotidok) szerepének, illetve a génexpresszió szabályozásában betöltött feladatuknak is mindinkább részletes az irodalma $(31,32,33)$. Az elmúlt években igen sok ígéretes jelöltet sikerült azonosítani, amelyek akár a kardiális regenerációt is célozhatják (51).

A miRNS-terápiák között effektivitást sikerült igazolni posztinfarktusos modellekben $(37,38)$, hipertrófia (39), különböző aritmiák (35) és kardiális fibrózis (36) esetén is. Ezek között külön említendő egy szívelégtelenség-modellel végzett tanulmány, amelyben az intracelluláris kalciumszabályozás módosítására miRNS-25 ASO-alkalmazás során a kardiális kontraktilitás volt fokozható (61). Egy másik, igen aktuális közleményben pedig iszkémiás szívelégtelen sertésmodell alkalmazásával miR-132-inhibitorral sikerült dózisfüggően balkamra-funkciójavulást kimutatni az 56 napos követés során (67).

A miRNS-ek, vagy épp a különböző RNS-formákat 
módosító oligonukleotidok legfőbb veszélye egyelőre, hogy hatásuk nem specifikus, és sok esetben nem csak egy szabályozási folyamatban vesznek részt. Egy miRNS több gén expressziójára is hatással lehet. Ezekre sok esetben nem is azonnal derül fény. A hátrányok között említendő, hogy jelenleg a miRNS-terápiák tervezett hatásán kívüli változások monitorozására biztos vizsgáló módszer nem áll rendelkezésre (40).

\section{Zárógondolat}

Az összefoglaló áttekintés a kardiális regeneráció aktuális kérdéseire próbál rávilágítani. Terjedelméből fakadóan kevésbé tud koncentrálni a különböző részekben az ismeretek részletező leírására, így ezek a releváns, feltüntetett irodalomból érhetőek el. Az írás legfőbb célja a jelenleg elérhető megoldási alternatívák és a kutatási terület sokszínűségének bemutatása, egyben kiemelni a módosított mRNS-terápiával történt eddigi biztató eredményeket.

A kardiális regenerációt sok oldalról megközelítő kutatási projektek számos megoldandó problémát is fókuszba helyeznek. A nem celluláris formák rendkívüli lehetőséget jelentenek ezen nehézségek áthidalására, a szív szöveti helyreállítására. A jelenleg is folyamatban lévő humánvizsgálatok sokunkat bizakodóvá tehetnek. Remélhetőleg a közeljövőben az újabb terápiák akár a mindennapi orvosi gyakorlatba is bekerülhetnek.

\section{Nyilatkozat}

A szerző kijelenti, hogy az összefoglaló közlemény megírásával kapcsolatban nem áll fenn vele szemben pénzügyi vagy egyéb lényeges összeütközés, összeférhetetlenségi ok, amelyek befolyásolhatják a közleményben bemutatott eredményeket, az abból levont következtetéseket vagy azok értelmezését.

\section{Irodalom}

1. Benjamin EJ, Muntner P, Virani SS, et al. Heart Disease and Stroke Statistics-2019 Update: A Report From the American Heart Association. Circulation 2019; 139: e56-528. doi: 10.1161/ CIR.0000000000000659

2. Santos JV, Souza J, Freitas A, et al. The state of health in the European Union (EU-28) in 2017: an analysis of the burden of diseases and injuries. Eur J Public Health 2019. doi: 10.1093/eurpub/ckz203

3. Conrad N, Judge A, Rahimi K, et al. Temporal trends and patterns in heart failure incidence: a population-based study of 4 million individuals. Lancet 2017; 391: 572-580. doi: 10.1016/S01406736(17)32520-5

4. Severino P, Mather PJ, Fedele F, et al. Advanced Heart Failure and End-Stage Heart Failure: Does a Difference Exist Diagnostics. 2019. pii: E170. doi: 10.3390/diagnostics 9040170

5. Anversa P, Leri A, Kajstura J. Cardiac regeneration. J Am Coll Cardiol 2006; 47: 1769-76. doi: 10.1016/j.jacc.2006.02.003

6. Bergmann O, Bhardwaj RD, Frisen J, et al. Evidence for cardiomyocyte renewal in humans. Science 2009; 324: 98-102. doi: 10.1126/science. 1164680

7. Porrello ER, Mahmoud AI, Sadek HA, et al. Transient regenerative potential of the neonatal mouse heart. Science 2011; 6020: 1078-1080. doi: 10.1126/science. 1200708

8. Balsam LB, Wager AJ, Robbins RC, et al. Haematopoietic stem cells adopt mature haematopoietic fates in ischaemic myocardium. Nature 2004; 6983; 668-673. doi: 10/1038/nature02460

9. Protze S, Khattak S, Ravens U, et al. A new approach to transcription factor screening for reprogramming of fibroblasts to cardiomyocyte-like cells. J Mol Cell Cardiol 2012; 53: 323-332. doi: 10.1016/j.yjmcc.2012.04.010

10. Qian L, Huang Y, Srivastava D, et al. In vivo reprogramming of murine cardiac fibroblasts into induced cardiomyocytes. Nature 2012; 7400: 593-598. doi: 10.1038/nature11044

11. Schultz BR, Chamberlain JS. Recombinant adeno-associated virus transduction and integration. Mol Ther 2008; 16: 1189-1199. doi: $10.1038 / \mathrm{mt} .2008 .103$

12. Wang Z, Troilo PJ, Ledwith BJ, et al. Detection of integration of plasmid DNA into host genomic DNA following intramuscular injection and electroporation. Gene Ther 2004; 11: 711-721. doi: 10.1038/ sj.gt. 3302213

13. Wolff JA, Malone RW, FElgner PA, et al. Direct gene transfer into mouse muscle in vivo. Science 1990; 4949: 1465-8. doi: 10.1126/ science.1690918

14. Dyer KD, Rosenberg HF. The RNase a superfamily: generation of diversity and innate host defense. Mol Divers 2006; 10: 585-597. doi: 10/1007/s11030-006-9028-2

15. Rigby RE, Rehwinkel J. RNA degradation in antiviral immunity and autoimmunity. Trends Immunol 2015; 36: 179-188. doi: 10.1016/j.it.2015.02.001

16. Heil F, Hemmi H, Bauer S, et al. Species-specific recognition of single-stranded RNA via toll-like receptor 7 and 8. Science 2004 5663: 1526-1529. doi: 10.1126/science.1093620

17. Diebold SS, Kaisho T, Reis e Sousa C, et al. Innate antiviral responses by means of TLR7-mediated recognition of single-stranded RNA. Science 2004; 5663: 1529-1531. doi: 10.1126/science.1093616

18. Alexopoulou L, Holt AC, Flavell RA, et al. Recognition of double-stranded RNA and activation of NF-kappaB by Toll-like receptor 3. Nature 2001; 6857: 732-738. doi: 10.1038/35099560

19. Schlee M, Roth A, Hartmann G, et al. Recognition of 5' triphosphate by RIG-I helicase requires short blunt double-stranded RNA as contained in panhandle of negative-strand virus. Immunity 2009; 31 : 25-34. doi: 10.1016/j.immuni.2009.05.008

20. Kariko K, Buckstein M, Weissman D, et al. Suppression of RNA recognition by Toll-like receptors: the impact of nucleoside modification and the evolutionary origin of RNA. Immunity 2005; 23: 165175. doi: 10/1016/j.immuni.2005.06.008

21. Kariko K, Muramatsu H, Weissman D, et al. Incorporation of pseudouridine into mRNA yields superior nonimmunogenic vector with increased translational capacity and biological stability. Mol Ther 2008; 16: 1833-1840. doi: 10.1038/mt.2008.200

22. Zangi L, Lui KO, Chien KR, et al. Modified mRNA directs the fate of heart progenitor cells and induces vascular regeneration after myocardial infarction. Nat Biotechnol 2013; 31: 898-907. doi: 10.1038/nbt. 2682

23. Katz MG, Fargnoli AS, Bridges CR, et al. The road ahead: working towards effective clinical translation of myocardial gene therapies. Ther Deliv 2014; 5: 39-51. doi: 10.4155/tde.13.134

24. Islam MA, Reesor EK, Shi J, et al. Biomaterials for mRNA delivery. Biomater Sci 2015; 12: 1519-1533. doi: 10.1039/c5bm00198f

25. Li L, Wei Y, Gong C. Polymeric Nanocarriers for Non-Viral Gene Delivery. J Biomed Nanotechnol 2015; 11: 739-770. doi: 10.1166/ jbn.2015.2069

26. Huang CL, Leblond AL, Caplice NM, et al. Synthetic chemically modified mRNA-based delivery of cytoprotective factor promotes early cardiomyocyte survival post-acute myocardial infarction. Mol Pharm 2015; 12: 991-996. doi: 10.1021/mp5006239

27. Ginn SL, Amaya AK, Abedi MR, et al. Gene therapy clinical trials worldwide to 2017: An update. J Gene Med 2018; 20: e3015. doi: 


\subsection{2/jgm.3015}

28. Sultana N, Magadum A, Zangi L, et al. Optimizing Cardiac Delivery of Modified mRNA. Mol Ther 2017; 25: 1306-1315. doi: 10.1016/j.ymthe.2017.03.016

29. Magadum A, Singh N, Zangi L, et al. Ablation of a Single N-Glycosylation Site in Human FSTL 1 Induces Cardiomyocyte Proliferation and Cardiac Regeneration. Mol Ther Nucleic Acids 2018; 13 : 133-143. doi: 10.1016/j.omtn.2018.08.021

30. Savarese G, Lund LH. Global Public Health Burden of Heart Failure. Card Fail Rev 2017; 3: 7-11. doi: 10.15420/cfr.2016:25:2 31. Sullenger BA, NAir S. From the RNA world to the clinic. Science 2016; 6292: 1417-1420. doi: 10.1126/science.aad8709

32. Devaux Y, Zangrando J, Heymans S, et al. Long noncoding RNAs in cardiac development and ageing. Nat Rev Cardiol 2015; 12 : 415-425. doi: 10.1038/nrcardio.2015.55

33. Thum T. Noncoding RNAs and myocardial fibrosis. Nat Rec Cardiol 2014; 11: 655-663. doi: 10.1038/nrcardio.2014.125

34. Gonzales-Rosa JM, Burns CE, Burns CG. Zebrafish heart regeneration: 15 years of discoveries. Regeneration 2017; 4: 105-123. doi: $10.1002 /$ reg2.83

35. Quattrocelli M, Crippa S, Sampaolesi M, et al. Long-term miR-669a therapy alleviates chronic dilated cardiomyopathy in dystrophic mice. J. Am Heart Assoc 2013; 20: e000284 doi: 10.1161/ JAHA.113.000284

36. Tao L, Bei Y, Li X, et al. Crucial Role of miR-433 in Regulating Cardiac Fibrosis. Theranostics 2016; 12: 2068-2083. doi:10.7150/ thno.15007

37. Wang X, Ha T, Li C, et al. Increased expression of microRNA146 a decreases myocardial ischaemia/reperfusion injury. Cardiovasc Res 2013; 97: 432-442. doi: 10.1093/cvr/cvs356

38. Li Q, Xie J, Xu B, et al. Overexpression of microRNA-99a attenuates heart remodeling and improves cardiac performance after myocardial infarction. J Cell Mol Med 2014; 18: 919-928. doi: $10.1111 / \mathrm{jcmm} .12242$

39. Ganesan J, Ramanujam D, Engelhardt S, et al. MiR-378 controls cardiac hypertrophy by combined repression of mitogen-activated protein kinase pathway factors. Circulation 2013; 127: 2097-2106. doi: 10.1161/CIRCULATIONAHA.112.000882

40. Willms E, Johansson HJ, Vader P, et al. Cells release subpopulations of exosomes with distinct molecular and biological properties. Sci Rep 2016; 6: 22519. doi: 10.1038/srep22519

41. Valadi H, Ekström K, Lötvall JO, et al. Exosome-mediated transfer of mRNAs and microRNAs is a novel mechanism of genetic exchange between cells. Nat Cell Biol 2007; 9: 654-659. doi: 10.1038/ ncb1596

42. Sanganalmath SK, Bolli R. Cell therapy for heart failure: a comprehensive overview of experimental and clinical studies, current challenges, and future directions. Circ res 2013; 113: 810-834. doi: 10.1161/CIRCRESAHA.113.300219

43. Vaganozzi RJ, Maillet M, Molkentin JD. An acute immune response underlies the benefit of cardiac stem cell therapy. Nature 2020; 7790: 45-409. doi: 10.1038/s41586-019-1802-2

44. Engel FB, Schebesta M, Keating MT, et al. p38 MAP kinase inhibition enables proliferation of adult mammalian cardiomyocytes. Genes Dev 2005; 19: 1175-1178. doi: 10.1101/gad. 1306705

45. Bassat E, Mutlak YE, Tzahor E, et al. The extracellular matrix protein agrin promotes heart regeneration in mice. Nature 2017; 7662: 179-184. doi: 10.1038/nature22978

46. Wei K, Serpooshan V, Ruiz-Lozano P, et al. Epicardial FSTL1 reconstitution regenerates the adult mammalian heart. Nature 2015; 7570: 479-485. doi: 10.1038/nature15372

47. Kühn B, del Monte $F$, Keating $M T$, et al. Periostin induces proliferation of differentiated cardiomyocytes and promotes cardiac repair. Nat Med 2007; 13: 962-969. doi: 10.1038/nm1619

48. leda $M, F u$ JD, Srivastava $D$, et al. Direct reprogramming of fibroblasts into functional cardiomyocytes by defined factors. Cell
2010; 142: 375-386. doi: 10.1016/j.cell.2010.07.002

49. Losordo DW, Vale PR, Isner JM, et al. Gene therapy for myocardial angiogenesis: initial clinical results with direct myocardial injection of phVEGF165 as sole therapy for myocardial ischemia. Circulation 1998; 98: 2800-2804. doi: 10.1161/01.CIR.98.25.2800

50. Sato K, Wu T, Post MJ, et al. Efficacy of intracoronary or intravenous VEGF165 in a pig model of chronic myocardial ischemia. J Am Coll Cardiol 2001; 37: 616-623. doi: 10.1016/S07351097(00)01144-X

51. Eulalio A, Mano M, Giacca M, et al. Functional screening identifies miRNAs inducing cardiac regeneration. Nature 2012; 7429: 376-381. doi: 10.1038/nature11739

52. Ogura Y, Ouchi N, Murohara T, et al. Therapeutic impact of follistatin-like 1 on myocardial ischemic injury in preclinical models. Circulation 2012; 126: 1728-38. doi: 10.1161/CIRCULATIONAHA.112.115089 53. Turnbull IC, Eltoukhy AA, Costa KD, et al. Lipidoid mRNA Nanoparticles for Myocardial Delivery in Rodents. Methods Mol Biol 2017; 1521: 153-166. doi: 10.1007/978-1-4939-6588-5_10

54. Lui KO, Zangi L, Chien KR, et al. Driving vascular endothelial cell fate of human multipotent IsI1+ heart progenitors with VEGF modified mRNA. Cell Res 2013; 23: 1172-1186. doi: 10.1038/cr.2013.112 55. Svitkin YV, Chen YM, Sonenberg N, et al. N1-methyl-pseudouridine in mRNA enhances translation through elF2 $\alpha$-dependent and independent mechanisms by increasing ribosome density. Nucleid Acids Res 2017; 45: 6023-6036. doi: 10.1093/nar/gkx135

56. Mohamed TMA, Ang YS, Srivastava D, et al. Regulation of Cell Cycle to Stimulate Adult Cardiomyocyte Proliferation and Cardiac Regeneration. Cell 2018; 173: 104-116. doi: 10.1016/j.cell.2018.02.014 57. Tzahor E, Poss KD. Cardiac regeneration strategies: Staying young at heart. Scince 2017; 6342: 1035-1039. doi: 10.1126/science.aam5894

58. Hausenloy DJ, Yellon DM. Cardioprotective growth factors. Cardiovasc Res 2009; 83: 179-194. doi: 10.1093/cvr/cvp062

59. Dai W, Kloner RA. Cardioprotection of insulin-like growth factor-1 during reperfusion therapy: what is the underlying mechanism or mechanisms? Circ Cardiovasc Interv 2011; 4: 311-313. doi: 10.1161/CIRCINTERVENTIONS.111.964049

60. Gao R, Zhang J, Zhou M, et al. A Phase II, randomized, doubleblind, multicenter, based on standard therapy, placebo-controlled study of the efficacy and safety of recombinant human neuregulin-1 in patients with chronic heart failure. J Am Coll Cardiol 2010: 55: 1907-1914. doi: 10.1016/j.jacc.2009.12.044

61. Wahlquist $C$, Jeong $D$, Mercola $M$, et al. Inhibition of miR-25 improves cardiac contractility in the failing heart. Nature $2014 ; 7497$ : 531-535. doi: 10.1038/nature13073

62. Gan LM, Langerström-Fermer M, Fritsche-Danielson R, et al. Intradermal delivery of modified mRNA encoding VEGF-A in patients with type 2 diabetes. Nat Commun 2019; 20: 871. doi: 10.1038/ s41467-019-08852-4

63. Wang H, Paulsen MJ, Woo YJ, et al. Natural Heart Regeneration in a Neonatal Rat Myocardial Infarction Model. Cells 2020; 16: e229. doi: $10.3390 /$ cells 9010229

64. Lock MC, Tellam RL, Morrison JL, et al. Differential gene responses three days following infarction in the fetal and adolescent sheep heart. Physiol Genomics 2020. doi: 10.1152/physiolgenomics.00092.2019.

65. Eschenhagen T, Bolli R, Hill JA, et al. Cardiomyocyte Regeneration: A Consensus Statement. Circulation 2017; 136: 680-686. doi: 10.1161/CIRCULATIONAHA.117.029343

66. Hadas Y, Vincek AS, Zangi L. Altering Sphingolipid Metabolism Attenuates Cell Death and Inflammatory Response after Myocardial Infarction. Circulation 2020; 10: 1161. doi: 10.1161/CIRCULATIONAHA.119.041882

67. Foinquinos A, Batkai S, Thum T. Preclinical development of a miR-132 inhibitor for heart failure treatment. Nat Commun 2020; 11 : 633. doi: 10.1038/s41467-020-14349-2 